\title{
Sports, Brand America and U.S. public diplomacy during the presidency of Donald Trump
}

\author{
Yoav Dubinsky ${ }^{1}$ id
}

Revised: 23 July 2021 / Accepted: 1 September 2021 / Published online: 14 September 2021

(c) The Author(s), under exclusive licence to Springer Nature Limited 2021

\begin{abstract}
During Donald Trump's chaotic presidency, the intersections between sports and society transcended from the American context into a global one. While Trump's rhetoric and policies caused divisions in the United States and abroad, they also provoked counter-reactions from different stakeholders in American sports that led to long-overdue needed structural change and even diplomatic achievement when bidding for international events. The article explores, discusses, and analyzes the roles of sports in Brand America and in U.S. public diplomacy during Trump's time in the White House. The article is significant as it furthers the discussion on future trends in sports, nation branding, public diplomacy, and country image, and on the place of the United States in the international system of a changing world.
\end{abstract}

Keywords Sports diplomacy $\cdot$ Soft power $\cdot$ International relations $\cdot$ Nation branding $\cdot$ The United States

\section{Introduction}

The purpose of this article is to explore, discuss and analyze the role of sports in nation branding, public diplomacy, and country image in the United States (USA) during the presidency of Donald Trump. When coming down the escalators of Trump Tower in June 2015 and announcing his presidential candidacy, Donald Trump, spoke about the need to rebrand the USA in the minds of domestic publics, using the words "make America great again" (Time Staff 2015). Trump emphasized how foreign countries are taking advantage of existing American policies, and the need to change trade agreements, military priorities, and especially secure borders and limit illegal immigration from Mexico, famously saying: "They're sending people that have lots of problems, and they're bringing those problems with us. They're bringing drugs. They're bringing crime. They're rapists. And some, I assume, are good people" (Time Staff 2015).

Since that speech, Trump consistently used negative rhetoric political strategy (Ross and Caldwell 2020), and through the use of Twitter, rallies, press conferences, and

Yoav Dubinsky

yoavd@uoregon.edu

1 Instructor of Sports Business, Lundquist College of Business, University of Oregon, Anstett 298D, Eugene, OR 97403, USA interviews, dominated and shaped the public discourse (Boucher and Thies 2019; Giroux 2019). Through populist rhetoric, using rage, victimhood (Kelly 2020), simple language (Kayam 2018), and authoritarian ideology that appeals to fascist ideas (Giroux 2019), Trump constantly positioned himself as a successful businessman and an antipolitician (Kayam 2018) that will bring a needed structural change to America. Through ultra-nationalism and antiglobalism (Giroux 2019; Kayam 2018), Trump used fascist politics and populist rhetoric while capitalizing on the constant media attention (Boucher and Thies 2019). Brown (2017) uses the term "apocalyptic populism" to describe "the chaos, and the calamity, the horror and even absurdity of Trump regime". According to Brown (2017),

....with 'Make American Great Again' barely masked as 'Make America White Male Again', Trump converted social and economic castration into a disinhibited grab for that white male entitlement - a grab by the pussy or racial slur, by xenophobia, by denigration of the weak, by affirming the 'poorly educated', by attacking the cosmopolitans and urban elite. (Brown 2017)

Donald Trump's 2016 presidential campaign intersected with sports several times until the elections. On one hand, from white coach Bob Knight introducing him in a rally in Indiana, through dismissing bragging about sexual assault 
as "locker room banter" (Nelson 2017), to criticizing Colin Kaepernick for not standing in the national anthem and calling him to "find another country", Trump used sports to appeal to his base (Tinsley 2017). On the other hand, from women's golf in the LGPA Tour, through Kareem Abdul Jabbar and African American athletes, to the MLB Latin community, the sports world has also resisted Trump's rhetoric. Such ambiguous relations continued after the elections, as President-Elect Trump was visited by athletes such as Floyd Mayweather, Jim Brown, and Ray Lewis and criticized the NFL for losing ratings due to protest during the national anthem, while also being criticized by leading athletes such as LeBron James.

During Donald Trump's controversial presidency, the intersections between sports and society transcended from the domestic context into a global one on issues such as race, gender, nationalism, globalism, and American values (Boykoff and Carrington 2020; Fredrick et al. 2020; Murray 2019; Schmidt et al 2018). Through his presidency, Trump's administration used chaos as a policy of governance - a tactic used by authoritarian regimes and poses threats to democracy (Joseph 2017). According to Joseph (2017), chaos stimulates hate crimes, and the victims are blamed for the chaos. Yet, what is seemed like chaos can also be seen as a strategy to create energy (Kumar 2020). This article explores and discusses intersections of sports, public diplomacy, nation branding, country image, and the role of the USA in the international system during Trump's presidency from his inauguration in January 2017 to the inauguration of his successor, President Joe Biden, in January 2021. The article argues that while Trump's rhetoric continued to be divisive, racist, and xenophobic, and his time in office was indeed chaotic, US's sports diplomacy and Brand America reached some diplomatic achievements that previous administrations were not been able to achieve. Furthermore, the article argues that the created chaos led to counter-reactions and to long-overdue change.

\section{Sports, Nation Branding, and Public Diplomacy in America}

Country images are studied through multiple fields, perspectives, and lenses, such as business studies, social psychology, communication, and political science. According to Buhmann and Ingenhoff (2015) "country images are both the cause and effect of social as well of psychological processes, together with the multitude of their possible economic, cultural, and political effects" (p. 104). They offer a four-dimensional model to analyze countries' images: the functional dimension referring to the competences and competitiveness of a country, the normative dimension referring to beliefs regarding the integrity of the norms and values of a country, the aesthetic dimension referring the beautify and the cultural and scenery attractiveness, which all lead to the sympathetic dimension which captures the general feelings and fascination of a country (Buhmann and Ingenhoff 2015).

The term public diplomacy was introduced in the 1960s referring to "the conduct of foreign policy through engagement with international publics" (Cull 2010, p.11). Traditional definitions of public diplomacy emphasize the use of communication with foreign publics as a tool for government, organizations, and individuals to try and achieve a more favorable image of the country and ultimately improve foreign policy goals (Cull 2008; Gilboa 2006; Nye 2004). More contemporary definitions also analyze the role of private citizens through people-to-people diplomacy (Handelman 2012), private companies influencing a country's image through commerce as corporate diplomacy (OrdeixRigo and Durate 2009; White 2015). Public diplomacy falls under the umbrella term of soft power (Nye 2004), a term coined by political scientist Joseph Nye that pertains to the attempts to achieve foreign policy goals through attractions, rather than through military force and or economic sanctions. Other domains of soft power include culture, and shared values (Nye 2004). One manifestation of cultural diplomacy is through sports (Arning 2013; Signitzer and Coombs 1992).

After World War II and during the Cold War the USA used smart power, a combination of both soft power and hard power to shape its international image (Nye 2008). Using smart power the Untied States created alliances and achieved foreign policy goals (Nye 2008), which eventually led to the collapse of the Soviet Union, leaving the USA as the only superpower. According to Nye (2008), in the last decades "US foreign policy has tended to over-rely on hard power because it is the most direct and visible source of American strength" (p. 6). Since the invasion to Iraq in 2003 the image of the USA and Brand America has deteriorated and anti-American sentiments have increased (Martin 2007; Nye 2004, 2008). According to the Nation Brands Index, "disapproval of American invasion of Iraq affected the world's view of the American population American products, American culture, and even the American landscape itself" (Anholt 2010, p. 68). One way of analysis of the image of the USA over time is through The Good Country Index (2020), which measures what countries contribute to the world beyond their own borders. During Trump's Administration, the USA was ranked 38th overall, scoring especially low on international peace (108), on planet and climate from (82), and science and technology (48). The strongest ranking of the USA was 9th on health and wellbeing (The Good Country Index 2020). Some of the values attributed to Brand America are freedom and capitalism, along with arrogance, ignorance insensitivity, and selfabsorption (Martin 2007). 
In the context of sports, from a corporate diplomacy perspective, the sports business industry is also associated with some of the values embodied in Brand America, such as capitalism and individualism. Martin (2007) argues that the "Nike Swoosh is a badge that identifies the wearer as someone who's energetic and a bit of the rebel, whether rollerblading or lying in a hammock" (p. 99). Through the Cold War, the USA has been using sports for public diplomacy purposes through a variety of methods. Perhaps the two most famous examples were (a) "ping pond diplomacy" and the establishment of official relations with China developing from a friendly table tennis game between delegates in the 1970s, and (b) the USA leading a 60-countries boycott of the 1980 Moscow Olympic Games after the Soviet Union invaded Afghanistan (Murray 2019). The Soviet Bloc retaliated with a boycott of their own when the USA hosted the Olympic Games four years later in Los Angeles (Dubinsky 2019a). When looking at people-to-people diplomacy, through the "Black Power Salute" track and field athletes Tommy Smith and John Carlos manifested a protest against racial injustice in America, shedding a dark light about the liberal values the United States tries to associate with. From corporate diplomacy perspective, American companies have shaped and changed the Olympic Movement and global sports, through private sponsorships and television rights, making the Olympic Movement neglect its amateurish roots and adapt American capitalism (Dubinsky 2019b). The USA has hosted Olympic Games more times than any other country since their revival in 1896 .

The USA's use of sports for domestic and foreign policy transcends partisan politics. The neorealist paradigm positions the state's survival in the center of the international system prioritizes military strength and economic goals over international institutions, and is associated with right-wing parties (Legro and Moravcsik 1999). Yet, it was a Republican President, Richard Nixon, who visited China after a table tennis match (Pigman 2014). Furthermore, Republican Presidents signed two of the most important socially oriented laws that changed American sports: President Nixon signed Title IX, a law that prohibits discrimination based on gender in the American education system and led to American women dominating the Olympic Games in the twenty-first century (Graham 2016). Republican President George H. W. Bush signed the Americans with Disabilities Act, which prohibits discrimination based on disabilities in the public sphere and led to the development of Paralympic athletes (Woods and Butler 2021). On the other hand, although the left-wing is more associated with the liberal paradigm, that does emphasize the importance of collaborations and international institutions (Powell 1994), it was Democratic President Jimmy Carter who decided to boycott the 1980 Olympic Games for foreign policy purposes. As regardless of partisan politics the USA sees value in the role of sports in American foreign policy, sports diplomacy initiatives are officially part of the Bureau of Educational and Cultural Affairs (n.d.) at the U.S. Department of State. The U.S. Department of State's Sports Diplomacy Division, originally known as SportsUnited, was founded in the early 2000s in the wake of 9/11 (Bureau of Educational and Cultural Affairs, n.d). The office offers various programs for American citizens to travel overseas, uses American athletes as envoys and goodwill ambassadors (Bureau of Educational and Cultural Affairs, n.d; Cooper 2019), and initiates programs for non-American citizens to visit the USA, with sports being the bridge to promote American values. The focus on sports by the U.S. Department of State, regardless of partisan affiliation, is aligned with Nye's (2008) recommendation for America to rediscover its smart power.

\section{Chaos and governance in Trump's White House}

Through xenophobic, racist, and misogynistic rhetoric and policies, spreading lies and misinformation, dozens of scandals including two impeachments, paying hash money to a porn star, a revolving door of dozens of administrators fired or leaving, mishandling the COVID19 pandemic leading to hundreds of thousands of avoidable deaths, a mob of supporters violently storming the Capitol and not allowing a peaceful transition of power, and having his account suspended from Twitter and Facebook, Trump's administration has been chaotic (Giroux 2019; Heuman and Gonzalez 2018; Guerlin 2018). Trump used anti-politically correctness as a strategy (Kayam 2018), ridiculing people with disabilities, belittling political opponents, and repeatedly calling Democratic Senator Elizabeth Warren "Pocahontas" (Quealy 2021) making fun of her Native American ancestry claims. Internationally, the chaotic environment was incited and manifested by referring Haiti and African countries as "shithole" (Giroux 2019; Heuman and Gonzales 2018; Joseph 2017), anti-immigration policies where "brown bodies are re-confirmed as the enemy" (Heuman and Gonzales 2018, p. 338), promoting islamophobia and banning travel from Muslim countries (Joseph 2017), constantly calling COVID19 as the "Chinese virus" or "Kong Flu" (Frias 2020). According to Giroux (2019), some of Trump supporters and the Republican Party "bought into the script of ultra-nationalism, encouraged anti-Semitic mobs, embraced a militant masculinity, demonized racial and ethnic others, supported an unchecked militarism and fantasies of empire, and sanctioned state violence at home and abroad" (p. 718).

Chaos as a form of governance "has been used by fascist, authoritarian regimes, military and nonmilitary dictators, union-busting employers and reality-TV show host" (Joseph 2017, p. 486). Giroux argues that Trump "tapped 
into America's worst impulses" (p. 717) and that "his ultranationalism, white supremacist views, and racist diatribes coupled with his attack on immigrants, the media, AfricanAmericans, and Muslims are indicative of a politics right out the fascist playbook" (Giroux 2019, p. 717). Ross and Caldwell (2020) analyzed Trump's negative rhetoric through Twitter as a political strategy. Some of the most used keywords Trump used were "MakeAmericaGreatAgain", its' initials "MAGA", and "Americafirst" (Ross and Caldwell 2020 , p. 19). He was even compared to "Orwell's bogeyman dictator" (Rodden 2020, p. 260). One of the dangerous byproducts of using chaos as a tactic is creating disconnection (Joseph 2017). During Trump's Presidency, dozens of senior official administrators have been ousted or resigned, including high-level secretaries, chiefs-of-staff, press secretaries, senior advisors, and other officials (BBC World 2020; Seddiq 2020). Kumar (2018) argued that what is seemed as staff chaos, Trump sees as staff energy and uses that to lash at the media for loving to portray chaos in the White House. Lashing at the media and portraying news organizations as fake has also been a popular theme in Trump's social media use (Ross and Caldwell 2020).

As a populist leader, Trump often rejected multilateralism, withdrawing the U.S. from the Trans-Pacific Partnership, withdrawing from the Paris Climate Agreement, quitting UNESCO, quitting the UN Homan Rights Council, and pulling out with the Iran Deal (Friedman 2020; Schneiker 2020). Yet, part of the incoherency of Trump's presidency also includes forming a summit with North Korean leader Kim Jong-Un, moving the American embassy in Israel to Jerusalem, and taking a different approach to the Middle East, brokering normalization deals between Israel and several Arab and Muslim countries in the region. Thus, while there are various approaches to analyze if Trump's Presidency was un-purposefully chaotic, or strategically driven, there was much incoherency between the rhetoric, policies, and outcomes.

\section{Domestic power struggles shape international relations}

The social protests during Trump's presidency transcended from the American context to a global one, forcing national and international governing bodies to revise their policies. When Colin Kaepernick, former quarterback of the San Francisco 49ers, sat on the bench or knelt during the national anthem in preseason games in the fall of 2016, he was criticized by fans, media, and even teammates as "antiAmerican" and for being disrespectful to the U.S. military (Schmidt et al 2018). Kaepernick's protest was one of the peaks of what sociologist Dr. Harry Edwards (2016) identifies as the fourth wave of black athletes activism. The wave is characterized by "securing and transferring power via economic and technological capital" (Cooper et al. 2017 , p. 162), led by athletes who were already established financially and supported the Black Lives Matter (BLM) movement, including LeBron James. While most protests occurred domestically in American leagues, in September 2016, USWNT player Megan Rapinoe, knelt during the American anthem before an international friendly match between the USA against Thailand (Schmidt et al 2018). As a result, Kaepernick and Rapinoe were labeled "antiAmerican, anti-military, and anti-nationalist" (Schmidt et al 2018, 654), and US Soccer instituted a policy requiring athletes to stand during the national anthem. Although the protests were not directed towards a specific administration, Donald Trump criticized the protest and protesters, famously saying "Wouldn't you love to see one of these NFL owners, when somebody disrespects our flag, to say, 'Get that son of a bitch off the field right now. Out! He's fired. He's fired!'” (Boykoff and Carrington 2020). Yet, although Trump enjoyed the support of quite a few team owners (Cancian 2020), such comments caused counter-reactions that not only encouraged protests domestically, but led to policy changes pertaining as well to international sports (Carroll 2020; West 2020).

Through his presidency, Trump and American athletes criticized each other continuously through traditional media and social media. As a result, championship-winning teams and athletes refused the bi-partisan tradition to visit the White House or were not being invited (Gaines 2019). As the wave received support from more athletes, the business industry also embraced the protesters, including Nike (CNN 2018a). In the 2019 Pan American Games hammer thrower Gwen Berry and fencer Race Imboden won their competitions and protested during the playing of the American national anthem in their medal ceremonies (Sterling and Almasy 2019). Some of the change in policies could have been seen there, as the athletes did not suffer the same fate as Tommie Smith and John Carlos did when protesting in the 1968 Olympic Games and got kicked off the team, and only received 12 months probations (Sterling, and Almasy 2019). Thus, already by 2019, American athletes were challenging official policies of the USOPC and sports governing bodies, against protesting in international sports events, while some of the sponsors were supporting that form of activism.

The wave of protests in 2020, after the deaths of George Floyd, Breonna Taylor, and Jacob Blake, during the COVID19 pandemic, transcended races, genders, and even nationalities and resulted in sports organizations changing their policies. Edwards (2020) referred to the protests as a new, fifth wave, of activism. Although completing their season in "a bubble" in Orlando, NBA players were especially active, stopping to play after the shooting of Jacob Blake and forcing their owners to open the arenas as voting centers for 
the 2020 Presidential Elections to encourage voting from black communities who historically suffer from voter-suppression (Morse and Martin 2020). WNBA players were also extremely active on racial issues, especially Atlanta Dream players taking a stand against incumbent Senator and one of the team owners Kelly Loeffler supporting Democratic Senate candidate Raphael Warnock, which changed the political landscape in America (Gregory 2021). These protests led to cultural and policy changes in the USA and internationally. The counter-reaction of cancel culture and getting rid of offensive symbols ( $\mathrm{Ng} 2020)$ especially relating to racial history manifested through sports with NASCAR prohibited Confederation flags in races (ESPN News Service 2020) and even the State of Mississippi taking off the Confederate Flag from the state flag after pressure from student-athletes, the Southeastern Conference and the NCAA (Bromberg 2020). The NFL officially allowed protests (Romo 2020) and European soccer leagues integrated a policy of starting games with a moment of kneeling against racism (Grez 2020). Both US Soccer who forced the national team players to stand during the national anthem in 2017 and the USOPC who reprimanded the athletes who protested in the Pan American Games in 2019, changes their policies giving athletes a green light to protest during international events (Carroll 2020; West 2020).

Fearing politics will overshadow the Olympic Movement and the return of the mass Olympic boycotts of the 1970s and 1980s, IOC President, Thomas Bach, called to reconcile the freedom of speech with focusing on sports, writing that "Overwise, the Games will descend into a marketplace of demonstrations of all kinds, dividing and not uniting the world" (Bach 2020). Thus, the influence of internal pressure groups such as athletes and BLM on domestic and international policies, challenge the neorealist paradigm about the state being a unitary actor (Legro and Moravcsik 1999), forcing the international system to monitor and respond to domestic power struggles.

\section{The U.S. uses gender for diplomacy}

From the government, through the business industry, to private citizens, the USA uses a variety of methods to try to portray the country as a pioneer in women's sports, much due to Title IX, legislation from the 1970s, prohibiting discrimination in the education system based on sex (Woods and Butler 2021). As a result of Title IX, U.S. universities that enjoy millions of dollars generated through the men's football programs, have to give female athletes the same conditions the revenue-generating male athletes, giving American women a sustainable competitive advantage over international opponents where the sport is developed through clubs and not the education system. In the 2016 Olympic Games in Rio de Janeiro, not only American women won more medals than American men, they won 27 gold medals, a number of gold medals that only Great Britain won (Graham 2016). Furthermore, Title IX is an effective recruitment tool as thousands of international female-athletes study and compete in the USA as student-athletes (NCAA Research 2019), thus being exposed to the American culture and lifestyle while further improving the intercollegiate competition. Title IX also prohibits sexual assaults in universities. Thus, a culture of sexual abuse directly challenges the authenticity of the image the USA wants to project and can negatively impact the normative dimension of a country (Buhmann and Ingenhoff 2015).

One of the first public counter-reactions to Donald Trump's elections was the Women's March of 2017, when the day after his inauguration hundreds of thousands of women marched in Washington, DC, and millions marched across the rest of the USA and the world, protesting against misogyny and for social justice (Nelson 2017.). The marches were also a counter-reaction to Trump's misogynistic rhetoric, including the Access Hollywood tape where he brags about how people in power positions can force themselves on women and justified it as "locker room banter" (Nelson 2017). American athletes took part in the marches, including several US Women's National Team (USWNT) players (Solo 2017; Klingenberg 2017). Historically, the USWNT has been fighting for women's equality, breaking glass ceilings, along with dominating international competitions including before and after winning the 2019 FIFA Women's World Cup (The Daily Show with Trevor Noah 2019). Megan Rapinoe, co-captain of the USWNT in the 2019 FIFA World Cup, announced she would not go to the White House if the Americans will win the cup (Fredrick et al. 2020) and refused to sing the national anthem in protest of Trump's policies. In October 2017, the \#MeToo Movement, a feminist movement against sexual violence, exploded (Dastagir 2019), putting a spotlight on a systematic culture of sexual abuse, mostly by men in power positions. A few days later, Olympic champion McKayla Maroney (Mckayla 2017) shared on social media her story of being abused by former gymnastics doctor Larry Nassar, followed by the hashtag \#MeToo. The sexual abuse scandal in the U.S. Olympic Committee, USA Gymnastics, and Michigan State University, was exposed in late 2016 by the IndyStar newspaper in Indiana (Alesia et al. 2016; Lansing State Journal and IndyStar and USAToday Network, n.d.). Maroney's post, along with other athletes such as legendary team captain Aly Raisman, sharing their story, exposed the scandal to a much larger audience, leading to hundreds of more women to come forward about the abuse, and to waves of resignations (Lansing State Journal and IndyStar and USAToday Network, n.d.). 
According to Cull (2010), for public diplomacy to be effective, it must be connected to policy and requires credibility. The abuse by Larry Nassar occurred over decades, under the presidencies of Bill Clinton, George W. Bush, and Barack Obama (Alesia et al. 2016). While the image of resistance and fight for change enhances the reputation of Brand America as free and rebellious (Martin 2007), millions of women marching against Trump, against systematic sexual abuse, and a culture of entitlement by men in power taking advantage of their positions, can challenge the narrative of the U.S. being a world leader for women, including through sports. Although Trump "outlined funding cuts to every governmental department, except defense" (Murray 2019, pp. 122-123), The U.S. State Department supports several bi-partisan initiatives of using sports as a way to reach global audiences (Bureau of Education and Cultural Affairs, n.d.). Some of them are organized directly through the department, and some through partnerships with other organizations and universities. The International Visitor Leadership Program (IVLP) (n.d.) launched in 1940 and brought over 5,000 exchange participants to the U.S., over a period of 80 years. In 2019 the program focused on women in sports media focusing especially on "the strides that women and girls have made in the decades since Title IX, while also addressing the obstacles female sports journalists face in the United States and abroad" (Office of the Spokesperson 2019). Emphasizing the impacts of Title IX and the growth of women in American sports to strategic communities that can send the desired message as influencers or through foreign media outlets is just one of several programs and tactics the U.S. State Department uses to promote the image and reputation of the USA. "Step in, Dream Big" (n.d.) focuses on empowering girls and women through sports and includes a global mentoring program. Furthermore, dozens of female athletes served as envoys of the Department of State. Another example of a non-partisan sports diplomacy initiative is partnerships between the Department of State, universities, and the private industry. For example, the Center for Sport, Peace, and Society at the University of Tennessee leads the international women's empowerment program, as part of the U.S. Department of State and ESPNW Global Mentoring Program (bmaples 2019).

Positioning women in leading positions in sports did not necessarily need to come from the government. During Trump's administration, women broke institutional barriers in sports organizations, leagues, and teams. Susan Lyons was elected as the president of the United States Olympic \& Paralympic Committee (USOPC), Cindy Parlow Cone became the first female president of US Soccer, Becky Hammon became the first woman to coach in an NBA game, offensive assistant coach Katie Sowers coached at the Super Bowl, Kim Ng was appointed as the first female general manager in American professional sports, soccer goalkeeper Sarah Fuller became the first female athlete to play and score in a college football game in one of the "Power Five" conferences, and even the World Wrestling Entertainment had three women headlining WrestleMania in 2019, two of them being American and one Irish (Doggett 2019; Emmrich 2021; Peterson and Blum 2020; Team USA, n.d.). Thus, through bi-partisan public diplomacy, people-to-people diplomacy, and corporate diplomacy, American stakeholders much value in associating its image and policies as a leader for women in sports. When scandals, protests, and structural abuse occur, the credibility of the message is also being challenged, requiring more branding efforts to keep using Title IX and gender as an effective diplomatic tool.

\section{Brand America has questionable values}

Whether through official public diplomacy, people-to-people diplomacy, or corporate diplomacy, the history of American diplomacy through sports has been inconsistent and controversial. Not boycotting the 1936 Olympic Games held under Nazi Germany, leading 60 countries to boycott the 1980 Olympic Games in Moscow for political purposes, playing the victim when the Soviets retaliate four years later, and not boycotting the Olympic Games in the 2008 Beijing or the 2014 Winter Olympic Games in Sochi, demonstrate the functionalist and realist U.S. approach to international sports (Dubinsky 2019a, b; Murray 2019; Pigman 2014). American athletes and companies have been associated with doping scandals, including Lance Armstrong who was compared to the "mafia" (Busfield 2013) by the United States Anti-Doping Agency (USADA), and Marion Jones who served times in prison for lying to federal agents after being involved with the BALCO labs doping scandals (Associated Press 2008). During Trump's administration, it was the Nike Oregon Project, a project founded with the goal of making American distance runners competitive, who was caught involved with doping, after coach Alberto Salazar received a four-year ban for violating three doping codes (Sgobba 2019). Closing the Nike Oregon Project due to a doping scandal adds to Nike's history of controversies and criticism including abusing factory workers in sweatshops, intensive promotions that resulted in crime and violence, having inconsistent social messages (Minhong 2020). During Trump's presidency, while Russia received a doping ban from international competitions, international sports organizations have not sanctioned the USA. Although Nike remained a sponsor of Team USA even after the Nike Oregon Project doping scandal, and the USOPC failed to protect female athletes from being abused, not only the Americans did not receive international sanctions of being suspended, Los Angeles was awarded to host the 2028 Olympic Games. 
Brand America is associated with values such as freedom, capitalism, along with arrogance, ignorance, and selfabsorption (Martin 2007). During Trump's administration, some of these values have been contracting with each other, especially when there was potential for financial gain. For example, freedom of speech against China. While the NBA was one of the most progressive organizations supporting athletes activism, and LeBron James one of the leaders of the current waves, when Daryl Morey, former general manager of Houston Rockets, supported the protesters in Hong Kong against the Chinese government, he received domestic and international criticism (BBC News 2019). The league referred to the comment as "regrettable", and James as "misinformed". The NBA is estimated to be worth $\$ 5$ billion in China (Chinni 2019), and Murray's comments about a non-democratic country risked the partnership. Thus, the league and American values could be seen as hypocritic, pick-and-choosing when activism and freedom of speech could and should be celebrated, and choosing causes according to financial gain and dependency, rather than ethics. Other examples of how financial incentives provoked negative images of American were USWNT being portrayed as bullies and arrogant over-celebrating against Thailand in the 2019 FIFA World Cup, framing their action as part of their fight for equal pay (The Daily Show with Trevor Noah 2019), or top American NBA players deciding not to join the national team for the 2019 Mundobasket (Ziller 2019), in which the team eventually finished in the seventh place in one of the most American-dominated sports (Schuhmann 2019).

These examples pale in comparison to the chaos created in college athletics. During the COVID19 pandemic as different leagues, conferences, schools and even teams within the schools had different policies if to hold a season or not (Kalman-Lamb et al. 2020; Mirabito et al. 2020). While most divisions, conferences, and universities canceled their 2020 fall athletic competitions, Trump encouraged the "Power Five" conferences who generate billions of dollars to hold a football season (Vasquez and Carvajal 2020), which eventually happened. College football players generate billions of dollars through television rights, yet the studentathletes are not allowed to receive a salary. Although PAC12 players published an article in the Players Tribune (2020) threatening to opt-out of the season (Silva et al. 2020) unless several demands will be met, including "Distribute $50 \%$ of each sport's total conference revenue evenly among athletes in their respective sports" (The Players Tribune 2020). According to Borghesi (2017), in an open market, the salary value of college football players will vary between $\$ 21,000$ for a low-star player, not including tuition scholarships and accommodations, to $\$ 799,000$ for a five-star recruit. In an article published in the British Guardian, Silva, KalmanLamb and Mellis, portrayed universities and conferences using "union-busting" tactics. Only $2 \%$ of football college players going professionally, African-American being the lowest income demographics in America and over-represented in college football (Woods and Butler 2021), the sport that is already scrutinized for putting players at the risk of brain damage, and universities and conferences generate billions from the television rights and other forms of methods (Borghesi 2017). Eventually, all Power Five conferences held football seasons. By December 2020, college sports reported over 6,500 positive cases in athletic departments (Blinder et al. 2020). Inconsistent policies occurred in college basketball, another multi-million-dollar industry, with some conferences and universities making different decisions if to play, pause, or cancel their seasons (KalmanLamb et al. 2020; Mirabito et al. 2020), adding to the overall chaotic situation.

Time after time during his presidency, the Trump administration, and American sports organizations and athletes were confronted between choosing moral value or financial capital, and when push came to shove, decisions were morally questionable at best. Such decisions led to inconsistent and controversial policies and outcomes. As the credibility of public diplomacy is tied to good policies (Cull 2010) and an image of a country also depends on its normative dimension (Buhmann and Ingenhoff 2015), doping, cheating, criticizing speaking out against oppression, exploitation, and constantly choosing money over moral values, shed a dark light on American moral values.

\section{Sports diplomacy manifests in different forms}

During Trump's presidency, some of the intersection between traditional public diplomacy that pertains to foreign policy (Cull 2010), people-to-people diplomacy by private citizens (Handelman 2012), and corporate diplomacy through the private industry (Ordeix-Rigo 2009) could be seen through the role of basketball star Dennis Rodman in Trump's mixed relations with the Supreme Leader of North Korea Kim Jung-Un. Since 2013 Rodman visited North Korea several times for basketball purposes, establishing relations with Kim, yet the Obama administration has not followed up on that with forming official relations (Murray 2019). Although not being an official part of the delegations (Cooper 2019), Rodman traveled to Singapore for the Trump-Kim historic summit in 2018, going on CNN wearing a "Make America Great Again" and speaking about establishing his relations with the North Korean leader based on having good times and talking about basketball, bringing joy to the people of North Korea through sports, and being thanked by Trump's White House (CNN 2018b). According to Cooper (2019), Rodman's trip to Singapore was an 
example of "maverick behavior by celebrities in international relations" (p. 170) and was sponsored by PotCoin, a digital currency for cannabis. Another form of intersection between the different forms of diplomacy occurred when Trump's administration negotiated the release of three UCLA basketball players that were arrested in China after being caught shoplifting (Carroll 2017). This exemplifies the role of universities promoting American culture through an international basketball game between UCLA and Georgia Tech in Shanghai, the personal reputations of Americans misbehaving abroad, and the official roles of inter-government relations engaging in diplomacy leading to the release of the players

The only Olympic Games taking place during Trump's administrations were the 2018 Winter Olympic Games in PyeongChang in South Korea. Some forms of diplomacy could be seen through the Asian-American representation in Team USA. Korean-American gold medalist Chloe Kim and bronze medalists in figure skating Chinese American Nathen Chen, and Japanese-Americans Mirai Nagasu and the siblings Alex and Maia Shibutani, continue the legacy of Asian-Americans succeeding in the Winter Olympic Games and winter sports. The siblings were also official envoys of the U.S. Department of State, touring together with former world champion and Olympic Medalist Chinese-American Michelle Kwan, who became an official diplomat under Republican and Democratic administrations. From an American corporate diplomacy perspective and the Olympics, one of the most U.S.-recognized brands, McDonald's, stopped its partnership with the Olympic Movement (Guardia sport and agencies 2017) after 41 years. There was also a controversy about diversity around PyeongChang 2018, after openly gay bronze-winning medalist Adam Rippon declined to meet Vice President Mike Pence during the Winter Games, criticizing Pence's stands on gay conversion therapy (Sims 2018).

Another form of sports diplomacy manifested through winning bids to the 2024 Winter Universiade in Lake Placid in 2023, the 2026 FIFA World Cup together with Mexico and Canada, and the 2028 Olympic Games in Los Angeles (Hernandez 2009; Lake Placid 2023 2019; Ludvigsen 2019; United States Olympic Committee 2017). Hosting mega sports events embody opportunities for countries and communities to showcase their history and culture (Arning 2013), and achieve social, financial, and political goals (Dubinsky 2019a). Trump's xenophobic terminology and separatist foreign policy were overshadowed by both the Olympic bid and the FIFA World Cup bid emphasizing diversity and sustainability through the integration of minorities and using existing facilities or through collaboration with neighbor-countries (Ludvigsen 2019; United States Olympic Committee 2017). While during Barack Obama's presidency Chicago lost the bid to host the 2016 Olympic Games to Rio de Janeiro the USA lost to Qatar the bid to host the 2022 FIFA World Cup, Trump's era left a legacy to his successors of the USA being an attractive hosting country for mega-events.

Although not hosting the Olympic Games and not having the opportunity to use opening ceremonies for soft power (Arning 2013), American cultural diplomacy through sports could be seen through the Super Bowl. The Super Bowl is the most-watched annual televised event in the USA, connecting American football with the American way of life (Schimmel 2011) through traditions such as the national anthem, expensive and creative commercials, military-oriented rituals, and the halftime show. Among the American headlining artists performing in the halftime shows during Trump's presidency were Lady Gaga, Justin Timberlake, Maroon 5, and Jenifer Lopez (along with Shakira) (Fernandez 2020). During the 2020 half time show, Lopez, a Latino-American born to Puerto Rican parents, opened a feathered cape representing the flag of Puerto Rico while her daughter was singing "Born in the USA" and she was singing "Let's get loud" (Blest 2020). Such performance was interpreted as a protest against Trump's mishandling of the disaster of Hurricane Maria, his racist rhetoric, and anti-immigration policies. As Lopez explained, "Other people can try to build walls, keep us out or put us in cages. We are proud to recognize that all of us together is what makes this beautiful country truly great" (Shewfelt 2020). The Super Bowl halftime show can add to the aesthetic dimension of a country (Buhmann and Ingenhoff 2015) portraying the culture of the country as rich and diverse, but the protests can have a mixed impact on the normative dimension, shedding light on free speech, and on questionable moral values.

Several former presidents have been former athletes or doing sports recreationally during their time in the White House (Kiger 2019). Throughout his presidency, Trump was constantly playing golf, mostly in his owned golf clubs. Since coming into office, Trump visited his golf courses over 300 times, costing the taxpayer over $\$ 150$ million (Date 2020; Draper and Pennington 2021), played golf with former Japanese Prime Minister Shinzo Abe during the American President's visit to Japan (Liptak 2019) and awarded several golf players, including Tiger Woods, the President Medal of Freedom - the highest civil honor in the USA (Draper and Pennington 2021). However, after the attack on the Capitol, the Professional Golfers' Association of America (PGA of America) decided to move the planned 2022 PGA Championship from Trump National Golf Club in Bedminster, New Jersey. Whether through the U.S. President himself, the Department of State, organizations, corporations, university teams, diverse athletes, misbehaving athletes, maverick athletes, or celebrities, sports diplomacy manifested through Trump's presidency in various, and at-times-inconsistent 
and self-contradicting ways, sending a variety of mixedmessages about the image of America.

\section{Chaos creates energy but exposes the vulnerabilities of a country}

Kumar (2020) explained Trump's view of governance as creating energy by having administration officials leaving or fired through his presidency. The non-stop chaos during the four years at the White House, provoked pressure groups in America to demonstrate an active civil society, in which sports figures played a key role domestically and internationally, especially on race, ethnicity, gender, and American traditions and lifestyle. The chaos during Trump's presidency also exposed U.S. vulnerabilities. The lack of a nationally regulated healthcare system, along with an emphasis on personal freedom and the centrality of the economy, and mishandling by the administration, resulted in a social, financial, and health disaster, leading to hundreds of thousands of avoidable deaths. Such repeating failures pertain to the normative, functional, aesthetic, and sympathetic images of a country (Buhmann and Ingenhoff 2015).

Trump's presidency has been full of tragedy and violence, including the deadliest mass shooting in American history in Las Vegas in 2017. The Las Vegas Golder Knights commemorated the victims by retiring the number 58 , the number of people who died at that time from the shootings (Donato 2018). Amid several incidents of mass shootings, Gregg Popovich, head coach of Team USA who coached most of his career in San Antonio, Texas, and served in the American Air Force, questioned the rights to carry weapons and the relevance of the Second Amendment of the U.S. Constitution (Zillgitt 2018). Beyond the scandals, the resignations, and the pandemic, Trump himself continuously ignited chaos since running for office, appealing to far-right, white supremacists, neo-Nazis, leading "lock her up" chants against Hilary Clinton during the 2016 campaign, referring to some of the people marching in Charlottesville where neo-Nazis were shouting "Jews will not replace us" as "good people" and having "many sides" to the deadly events that followed, calling the Pride Boys to "stand back and stand by" during the 2020 presidential debate, and making false accusations about mass-elections fraud calling to his supporters not to go in peace on the day they stormed the U.S. Capitol (Giroux 2019; Heuman and Gonzales 2018; Kelly 2020; Pilkington 2018). The immediate response by the sports world came from athletes expressing their disgust not only with taking over the mob taking over the U.S. Congress but with the lack of response by law enforcement. While during the Black Lives Matter protests armed law enforcement officers were visible and active, during the storming of the Capitol people took selfies with security guards.
International media covered the reactions of the American sports world, covering different forms of protests in the NBA and citing athletes and coaches expressing their disgust, being ashamed, admitting "this is who we are", referring to the rioters as terrorists and systematic racism (Guardian sport and agencies 2021; TSN.ca staff 2020). The USA has been presented as anarchy by international media, and foreign press, world leaders and diplomats were questioning America's Democratic image, and its moral right to lecture other countries (Ellyatt 2021; Pop and Dube 2021). Several foreign and domestic politicians, including Austria-born former Republican Governor of California and ex-bodybuilding champion Arnold Schwarzenegger, compared the attack on the Capitol to the violence of the Nazis in Europe (Schwarzenegger 2021). Coach Popovich called to impeach Trump to send a message "to a world that's laughing at us" and that he is "embarrassed to be an American and see what people saw" (Petrini 2021).

Donald Trump's disastrous presidency ended with an insurrection attempt in which a former Olympic champion participated in wearing a Team USA jacket, a second impeachment which was supported by a national team coach, athletes and coaches quoted on international media that the USA is a racist country. While it is likely that the shame (Petrini 2021) and calamity (Brown 2017) had negative impacts on some of the normative and functional dimensions of the image of the USA (Ellyatt 2021; Pop and Dube 2021), the overall impact of sports on American nation branding and public diplomacy during Trump's presidency is more complex. While Trump used anti-politically correctness as a rhetoric strategy (Kayam 2018), insulting people with disabilities and calling racist names to political opponents, the world of sports constantly countered, usually with financial incentives. After pressure from sponsors, the Washington Redskins dropped the "Redskins" racist name that refers to a history of genocide of Native Americans (Furst 2020). The United States Olympic Committee changed its name to the United States Olympic and Paralympic Committee (2019) equaling medal monetary awards for medal-winning. The almost non-stop chaos under Trump's administration might have energized a more active civil society, starting addressed some long-due injustices, such as changing protests policies, not using racist names, allowing protests, and even considering fundamental changes in the structure of American sports through compensation of student-athletes with new legislations (McCollough 2021). American entrepreneurship manifested through technological solutions, enabling sports leagues such as the NBA to complete their season in "a bubble" in Florida (Kowitt 2020). On the other hand, ignoring science such as climate change or the pandemic for financial or political purposes, portrayed the U.S. as a lagging country, leading to mishandling annual natural disasters and to avoidable deaths. While thousands of Americans were dying 
daily from COVID19, in New Zealand, where the leadership made decisions based on science, three months after the outbreak of the pandemic rugby games were played in front of full stadiums in a coronavirus-free country (Grantland 2020). Donald Trump's presidency ended with an insurrection in which a former Olympic champion participated in, a second impeachment which was supported by a national team coach, athletes, and coaches quoted on international media that the United States is a racist country, and even Bill Belichick, one of the most successful NFL coaches in history who even wrote Trump a congratulation letter in 2016 declined to receive the Medal of Freedom (Gardner 2021). The ongoing chaos in Trump's White House and the countless counter-reactions exposed the vulnerabilities of the USA, leading to one disaster after another.

\section{Conclusion}

Through discussing roles of sports in U.S. public diplomacy and Brand America during Donald Trump's presidency, the article argued that the almost non-stop chaos led to avoidable disasters but also created counter-reactions leading to long-due change and some achievements that can potentially improve the USA's country image in the future. The article constantly showed that traditional definitions of public diplomacy (Gilboa 2006; Cull 2010) are not sufficient to explain the role of sports in international relations, and when analyzing sports in people-to-people diplomacy and corporate diplomacy, internal contradictions might arise. While the USA's aesthetic dimension (Buhmann and Ingenhoff 2015) might improve through hosting opportunities, the functional and normative dimensions of America are under scrutiny. The article sheds light on the internal contradictions of American values, and on the gaps between claims for freedom, democracy, and opportunities and a history of genocide, slavery, racial and gender discrimination, having contemporary manifestations of racism, misogyny, exploitation, and even an insurrection attempt which all have implications on sports and society and the image of the USA.

There are several limitations and delimitations to this article and much future research is needed. As the article does not attempt to measure how sports changed the image of the USA during Trump's administration, future studies should analyze how Trump's presidency impacted the USA's sympathetic dimension (Buhmann and Ingenhoff 2015). The international system is constantly changing along with the role of sports (Dubinsky 2019a; Murray 2019). The Brexit changes labor conditions in sports in Great Britain, Russia was banned for systematic doping, China won bids to host international sports events in the early 2020s, and in the Middle East, the newly established relations between Israel and a few Arab and Muslim countries embody athletic collaborations while Qatar's role in global sports keeps growing. The world of sports is bound to change, with unclear financial and health implications of COVID19, the ever-developing evolution of the sport-tech industry, the growth of esports beyond East Asia and already adapting markets, different legislations on gender and transgender athletes, and climate change and the ethical responsibilities of hosting countries, cities, and communities to sustainability and to this planet. To maintain its place in a leading position in the global system, the USA uses smart power (Nye 2008), employing both hard powers through military force and economic sanctions and soft power through public diplomacy, political values, and culture. Trump left office when American Democracy is being ridiculed around the world, thousands of Americans were dying daily from the pandemic, and influential sports figures expressing a lack of faith in the efficiency of American security forces and in American governmental institutions. Whether or not the USA's place as a hegemonic superpower is on the decline or not will depend on the following American administrations, including their use of sports for nation branding and public diplomacy.

\section{Declarations}

Conflict of interest The author states that there is no conflict of interest.

\section{References}

Alesia, M., M. Kwiatkowski, and T. Evans. September 20, 2016. Timeline: Former USA Gymnastics doctor Larry Nassar. IndyStar. https://www.indystar.com/story/news/2016/09/20/larry-nassartimeline/90733320/.

Arning, C. 2013. Soft power, ideology and symbolic manipulation in Summer Olympic Games opening ceremonies: A semiotic analysis. Social Semiotics 23: 523-544.

Associated Press. March 7, 2008. Jones begins 6-month federal prison sentence. ESPN. https://www.espn.com/olympics/trackandfield/ news/story?id $=3282477$.

Bach, T. October 24, 2020. The Olympics are about diversity and unity, not politics and profit. Boycotts don't work. The Guardian. https://www.theguardian.com/sport/2020/oct/24/the-olymp ics-are-about-diversity-and-unity-not-politics-and-profit-boyco tts-dont-work-thomas-bach.

BBC News. October 7, 2019. Daryl Morey backtracks after Hong Kong tweet causes Chinese backlash. BBC. https://www.bbc.com/news/ business-49956385.

BBC World. December 15, 2020. The White House revolving door: Who's gone? BBC. https://www.bbc.com/news/world-us-canada39826934.

Blest, P. February 3, 2020. Shakira and JLo sent Trump some not-sosubtle messages in their Super Bowl Show. Vice. https://www. vice.com/en/article/wxex 5n/shakira-and-jlo-sent-trump-somenot-so-subtle-messages-in-their-super-bowl-show. 
Blinder, A., L. Higgins, and B. Guggenheim. December 11, 2020. College sports has reported at least 6,629 virus cases. There are many more. New York Times. https://www.nytimes.com/2020/ 12/11/sports/coronavirus-college-sports-football.html.

bmaples. October 1, 2019. CSPS leads eight annual International Women's Empowerment Program. Center for Peace, and Society. https://sportandpeace.utk.edu/2019/10/01/csps-leadseighth-annual-international-womens-empowerment-program/.

Borghesi, R. 2017. Pay for play: The financial value of NCAA football players. Applied Economics 49 (46): 4657-4667. https:// doi.org/10.1080/00036846.2017.1287865.

Boucher, J., and C.G. Thies. 2019. "I am a tariff man": The power of populist foreign policy rhetoric under President Trump. The Journal of Politics 81 (2): 712-722. https://doi.org/10.1086/ 702229.

Boykoff, J., and B. Carrington. 2020. Sporting dissent: Colin Kaepernick, NFL activism and media framing contests. International Review for the Sociology of Sport 5 (7): 829-849. https://doi. org/10.1177/1012690219861594.

Bromberg, N. June 28, 2020. SEC, NCAA heads commend Mississippi for vote to change state flag. Yahoo! Sport. https://sports. yahoo.com/sec-commissioner-greg-sankey-commends-missi ssippi-for-vote-to-change-state-flag-232753396.html.

Brown, W. August 30, 2017. Apocalyptic populism. Eurozine. https://www.eurozine.com/apocalyptic-populism/.

Buhmann, A., and D. Ingenhoff. 2015. The 4D Model of the country image: An integrative approach from the perspective of communication management. The International Communication Gazette 77: 102-124.

Bureau of Education and Cultural Affairs. (n.d.). Sports Diplomacy. United States Department of State. https://eca.state.gov/sportsdiplomacy.

Busfield, S. and agencies. January 8, 2013. Lance Armstrong 'offered $\$ 250,000$ donation' to anti-doping agency. The Guardian. https://www.theguardian.com/sport/2013/jan/08/lance-armst rong-donation-usada-claim.

Cancian, D. June 15, 2020. Which NFL owners support Donald Trump? List of those who have donated to the President. Newsweek. https://www.newsweek.com/nfl-owners-support-donaldtrump-list-donated-president-1510841.

Carroll, R. November 15, 2017. UCLA players apologize for shoplifting in China, thank Trump. Reuters. https://www.reuters. com/article/us-usa-ucla-china-trump-idUSKBN1DF2VH.

Carroll, R. June 10, 2020. U.S. Soccer says it will allow protests during anthem. Reuters. https://www.reuters.com/article/ussoccer-usa-protests-idUSKBN23I02P.

Center for Sport, Peace, and Society. (n.d.). Global Exchanges. The University of Tennessee. https://sportandpeace.utk.edu/globalexchanges/.

Chinni, D. October 20, 2019. NBA's Hong Kong flare-up overloops deep U.S. investment in China. NBC News. https://www.nbcne ws.com/politics/meet-the-press/nba-s-hong-kong-flare-overl ooks-deep-u-s-investment-n1069096.

CNN. 2018a. Nike ad features Colin Kaepernick. CNN. https://www. cnn.com/videos/cnnmoney/2018/09/04/colin-kaepernick-nikead-controversy-nr-vpx.cnn.

CNN. 2018b. Dennis Rodman gets emotional after Trump-Kim summit. YouTube. https://www.youtube.com/watch?v=dAJLJ RRJY3E.

Cooper, A.F. 2019. U.S. public diplomacy and sports stars: Mobilizing African-American athletes as goodwill ambassadors from the cold war to an uncertain future. Place Branding \& Public Diplomacy 15: 165-172. https://doi.org/10.1057/ s41254-018-00114-2.

Cooper, J.N., C. Macaulay, and S.S. Rodriguez. 2017. Race and resistance: A typology of African American sport activism.
International Review for the Sociology of Sport 54 (2): 151-181. https://doi.org/10.1177/1012690217718170.

Cull, N.J. 2008. Public diplomacy: Taxonomies and histories. ANNALS of the American Academy of Political Science 616 (1): 31-54.

Cull, N.J. 2010. Public diplomacy: Seven lessons for its future from its past. Journal of Place Branding and Public Diplomacy 6: 11-17.

Draper, K., \& B. Pennington. January 10, 2021. Trump golf club loses 2022 P.G.A. Championship. New York Times. https://www.nytim es.com/2021/01/10/sports/golf/trump-pga-championship-moved. html?smtyp $=$ cur\&smid $=$ tw-nytimes.

Dastagir, A.E. September 30, 2019. It's been two years since the \#MeToo movement exploded. Now what? USA Today. https:// www.usatoday.com/story/news/nation/2019/09/30/me-toomovement-women-sexual-assault-harvey-weinstein-brett-kavan augh/1966463001/.

Date, S.V. 2020. Trump Back At Mar-A-Lago, Raising Taxpayer Golf Tab To \$151.5 Million, Huffington Post. https://www.huffpost. com/entry/trump-151-million-golf_n_5fe3bc61c5b6e1ce8338 3074 .

Doggett, E. April 8, 2019. Becky Lynch makes history by winning the main event at WWE WrestleMania 35. Irish Mirror. https:// www.irishmirror.ie/sport/other-sport/becky-lynch-makes-histo ry-winning-14251902.

Donato, C. April 1, 2018. Las Vegas Golden Knights honor 58 victims from last year's mass shooting. abc News. https://abcnews.go. com/Sports/las-vegas-golden-knights-honor-58-victims-years/ story? $\mathrm{id}=54157458$.

Dubinsky, Y. 2019a. Analyzing the roles of country image, nation branding, and public diplomacy through the evolution of the modern Olympic movement. Physical Culture and Sport Studies and Research 84 (1): 27-40. https://doi.org/10.2478/ pcssr-2019-0024.

Dubinsky, Y. 2019b. From soft power to sports diplomacy: A theoretical and conceptual discussion. Place Branding and Public Diplomacy. https://doi.org/10.1057/s41254-019-00116-8.

Edwards, H. 2016. $4^{\text {th }}$ Wave of Black Athletes in Political Protest Keynote Lecture. North American Society for the Sociology of Sport 2016 Conference, Tampa, FL. https://www.youtube.com/ watch? $\mathrm{v}=$ Oimoyy $\mathrm{x} 0 \mathrm{HpE}$.

Edwards, H. [@ drharryedwards]. August 27, 2020. To this 5Th Wave of activist athletes : be confident in your cause, empowered by your empathy, and sustained by the caliber of your commitment: Silence is evil's greatest ally! [Tweet]. Twitter. https://twitter. com/drharryedwards/status/1299217811160539136.

Ellyatt, H. January 7, 2021. 'Anarchy in the USA': Global media reacts to Capitol chaos. CNBC. https://www.cnbc.com/2021/01/07/ democracy-under-sge-chaos-and-anarchy-in-the-usa-and-globalmedia-.html.

Emmrich, S. January 1, 2021. Four women who broke through sports' glass ceiling in 2020. Vogue. https://www.vogue.com/article/ four-women-who-broke-sports-glass-ceiling-in-2020.

ESPN News Services. June 10, 2020. NASCAR bans Confederate flags from all racetracks. ESPN. https://www.espn.com/racing/nascar/ story/_/id/29293767/nascar-bans-confederate-flags-racetracks.

Fernandez, G. February 2, 2020. Super Bowl show 2020: Jennifer Lopez and Shakira about to join list of all-time halftime performers. CBS Sports. https://www.cbssports.com/nfl/news/superbowl-halftime-show-2020-jennifer-lopez-and-shakira-about-tojoin-list-of-all-time-halftime-performers/.

Fredrick, E.L., A. Pegoraro, and A. Schmidt. 2020. "I'm not going to

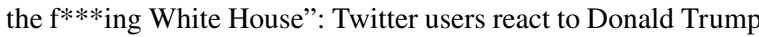
and Megan Rapinoe. Communication \& Sport. https://doi.org/ $10.1177 / 2167479520950778$.

Frias, L. July 11, 2020. Trump has a penchant for calling the coronavirus the 'Chinese Virus or 'Kung Flu.' Experts on Asian culture said the racist implications of the term divert attention from the 
disastrous US response. Insider. https://www.insider.com/exper ts-trump-racist-names-for-coronavirus-distract-from-us-respo nse-2020-7.

Friedman, L. November 4, 2020. U.S. quits Paris Climate Agreement. Questions and answers. New York Times. https://www.nytimes. com/2020/11/04/climate/paris-climate-agreement-trump.html.

Furst, R. July 14, 2020. American Indians in Minnesota celebrate as Washington changes its nickname. Star Tribune. https://www. startribune.com/american-indians-in-minnesota-celebrate-aswashington-redskins-ditch-their-nickname/571753392/.

Gaines, C. June 26, 2019. Championship teams visiting the White House has turned into a mess - here is how Trump and the teams have wrecked the tradition. Business Insider. https://www.businessinsider.com/championsh ip-teams-trump-white-house-2019-4.

Gardner, S. January 11, 2021. Patriots' Bill Belichick declines Medal of Freedom from Donald Trump, says he has 'great reverence' for democracy. USA Today. https://www.usatoday.com/story/ sports/nfl/patriots/2021/01/11/bill-belichick-patriots-declinesmedal-freedom-donald-trump/6632843002/.

Gilboa, E. 2006. Public diplomacy: The missing component in Israel's foreign policy. Israel Affairs 12: 715-747.

Giroux, H.A. 2019. Trump and the legacy of a menacing past. Cultural Studies 33 (4): 711-339. https://doi.org/10.1080/09502386.2018. 1557725.

Graham, B.A. August 23, 2016. How the women of the US Olympic team won big and smashed stereotypes. The Guardian. https:// www.theguardian.com/sport/2016/aug/23/team-usa-womenolympics-success-rio-2016.

Grantland, D. June 15, 2020. 43,000 fans pack stadium for rugby game after New Zealand beats coronavirus. SI. https://www.si.com/ extra-mustard/2020/06/15/new-zealand-super-rugby-coronavirus-fans-sellout.

Gregory, S. January 7, 2021. 'We did that': Inside the WNBA's strategy to support Raphael Warnock - and help Democrats win the Senate. Time. https://time.com/5927075/atlanta-dream-warno ck-loeffler/.

Grez, M. June 2, 2020. Premier League players urged to take a knee in protest at George Floyd's death. CNN. https://edition.cnn. com/2020/06/02/sport/george-floyd-kick-it-out-premier-leaguepogba-rashford-lewis-hamilton-spt-intl/index.html.

Guardian sport and agencies. June 16, 2017. McDonald's pulls out of Olympics contract to end 41-year sponsorship. The Guardian. https://www.theguardian.com/sport/2017/jun/16/mcdonaldspulls-out-olympics-contract-end-41-year-sponsorship.

Guardian sport and agencies. January 7, 2021. "This is who we are': NBA reacts in dismay at mob's invasion of US Capitol. The Guardian. https://www.theguardian.com/sport/2021/jan/06/ bucks-pistons-take-knee-celtics-heat.

Guerlin, P. 2018. US foreign policy of chaos under Trump: The wrecker and the puppeteers. LISA e-Journal. https://doi.org/10.4000/lisa. 10208.

Handelman, S. 2012. The minds of peace experiment: A laboratory for people-to-people diplomacy. Israel Affairs 18 (1): 1-11. https:// doi.org/10.1080/13537121.2012.634278.

Hernandez, B. October 2, 2009. Chicago loses Olympics to Rio de Janeiro. CBS News. https://www.cbsnews.com/news/chicagoloses-olympics-to-rio-de-janiero/.

Heuman, A.N., and A. Gonzalez. 2018. Trump's essentialist border rhetoric: Racial identities and dangerous liminalities. Journal of Intercultural Communication Research 47 (4): 326-342. https:// doi.org/10.1080/17475759.2018.1473280.

International Visitor Leadership Program (IVLP). (n.d.). At-a-Glance. Bureau of Educational and Cultural Affairs. https://exchanges. state.gov/non-us/program/international-visitor-leadership-progr am-ivlp.
Joseph, S. 2017. Chaos as a political strategy of governance. Journal of Middle East Women's Studies 13 (3): 486-488. https://doi.org/ 10.1215/15525864-4179188

Kalman-Lamb, S.D., and J. Mellis. December 21, 2020. College basketball needs to shut down during the COVID-19 Pandemic. Time. https://time.com/5922163/college-basketbal-covid-19/

Kayam, O. 2018. Donald Trump's Rhetoric. Language and Dialogue 8 (2): 183-208. https://doi.org/10.1075/ld.00012.kay.

Kelly, C.R. 2020. Donald J. Trump and the rhetoric of ressentiment. Quarterly Journal of Speech 106 (1): 2-24. https://doi.org/10. $1080 / 00335630.2019 .1698756$.

Kiger, J.K. January 29, 2019. Oval Office athletes: President and the sports they played. History. https://www.history.com/news/uspresidents-athletes.

Klingenberg, M. [@meghankling]. January 21, 2017. I'm marching today \#WomensMarch \#extranasty the only good part of being away from USWNT teammates [Tweet]. Twitter. https://twitter. com/meghankling/status/822958019642212352.

Kowitt, B. October 19, 2020. What business can learn from the NBA bubble. Fortune. https://fortune.com/2020/10/19/reinvent-podca st-nba-bubble/.

Kumar, M.J. 2020. The contemporary presidency Energy or Chaos? Turnover at the top of President Trump's White House. Presidential Studies Quarterly 49 (1): 219-236. https://doi.org/10. $1111 /$ psq. 12515.

Lake Placid 2023. 2019. Lake Placid Winter University Games history. https://www.lakeplacid2023.com/logo-history/.

Lansing State Journal and IndyStar and USAToday Network. (n.d.). Who is Larry Nassar? IndyStar. https://www.indystar.com/pages/ interactives/larry-nassar-timeline/.

Legro, J.W., and A. Moravcsik. 1999. Is anybody still a realist? International Security 24 (2): 5-55.

Liptak, K. May 26, 2019. Sumo, golf and barbeque: Trump and Abe bond after a tweet underscored divides. CNN. https://www.cnn. com/2019/05/25/politics/donald-trump-japan-sumo-abe/index. html.

Ludvigsen, J.A. 2019. "Continent-wide" sports spectacles: The "multiple host format" of Euro 2020 and United 2026 and its implications. Journal of Convention \& Event Tourism 20 (2): 163-181. https://doi.org/10.1080/15470148.2019.1589609.

Martin, D. 2007. Rebuilding brand America: What we must do to restore our reputation and safeguard the future of American business abroad. New York: Amacom.

McCollough, B.J. January 9, 2021. Commentary: After Senate flip, Congress won't save NCAA from athlete rights reckoning. Los Angeles Times. https://www.latimes.com/sports/story/2021-0109/congress-ncaa-nil-student-athletes?fbclid=IwAR3 wPl1U OvgOYxiuk5e2md5mLkVqA4ABFROZWBKfcu28153bJOqUt hXQib4.

Mckayla. [McKaylaMaroney]. October 18, 2017. \#MeToo [Tweet]. Twitter. https://twitter.com/McKaylaMaroney/status/9205485288 70400001/photo/1.

Minhong, K. 2020. How phil knight made nike a leader in the sport industry: Examining the success factors. Sport in Society 23 (9): 1512-1523. https://doi.org/10.1080/17430437.2020.1734329.

Mirabito, T., R. Hardin, and J.R. Pate. 2020. The fractured messaging of the National Collegiate Athletic Association and its members in response to COVID-19. International Journal of Sport Communication 13: 324-334. https://doi.org/10.1123/ijsc.2020-0249.

Morse, B., and J. Martin. August 29, 2020. NBA, players say games will resume on Saturday and arenas can be used for voting. $C N N$. https://edition.cnn.com/2020/08/28/sport/nba-michael-jordanpostpone-playoff-wnba-thursday-spt-intl/index.html.

Murray, S. 2019. Sports diplomacy: Origins, theory and practice. New York: Routledge. 
NCAA Research. 2019. Trends in the participation of international student-athletes in NCAA Divisions I and II. NCAA Research. https://ncaaorg.s3.amazonaws.com/research/demographics/ 2019RES_ISATrendsDivSprt.pdf.

Nelson, L. December 12, 2017. From 'locker room talk' on, Trump tends of misconduct claims. Politico. https://www.politico.com/ story/2017/12/12/trump-timeline-sexual-misconduct-allegationsdefense-292146.

$\mathrm{Ng}$, E. 2020. No grand pronouncements here...: Reflections on cancel culture and digital media participation. Television \& New Media 21 (6), 621-627. https://doi.org/10.1177/1527476420918828.

Nye, J.S., Jr. 2004. Soft power: The means to success in world politics. New York: PublicAffairs.

Nye, J.S., Jr. 2008. Public diplomacy and soft power. ANNALS of the American Academy of Political and Social Science 616 (1): 94-109.

Office of the spokesperson. November 4, 2019. New exchange program on women in sports media kick-off with international women sports journalists. U.S. Department of State. https://www.state. gov/new-exchange-program-on-women-in-sports-media-kicksoff-with-international-women-sports-journalists/.

Ordeix-Rigo, E., and J. Durate. 2009. From public diplomacy to corporate diplomacy: Increasing corporations' legitimacy and influence. American Behavioral Scientist 53 (4): 549-564. https://doi. org/10.1177/0002764209347630.

Peterson, A. M., \& Blum, R. March 12, 2020. Cindy Parlow Cone becomes 1st female president of US Soccer as Cordeiro steps down. $C B C$. https://www.cbc.ca/sports/soccer/usa-soccer-payequity-discrimination-lawsuit-1.5496226.

Petrini, T. January 7, 2021. Popovich blasts Trump and his allies after violent attack at U.S. Capitol. KENS5. https://www.kens5.com/ article/news/politics/popovich-sounds-off-on-violent-attackagainst-us-capitol/273-034d27b8-3f7d-4d5b-a313-515773828f df.

Pigman, G.A. 2014. International sport and diplomacy's public dimension: Governments, sporting federations and the global audience. Diplomacy \& Statecraft 25 (94): 94-114. https://doi.org/10.1080/ 09592296.2014.873613.

Pilkington, E. January 6, 2018. 'Stand back and stand by': how Trumpism led to the Capitol siege. The Guardian. https://www.thegu ardian.com/us-news/2021/jan/06/donald-trump-armed-protestcapitol.

Pop, V., \& Dube, R. January 7, 2021. World leaders are shocked, worried by Trump supporter's actions at U.S. Capitol. The Wall Street Journal. https://www.wsj.com/articles/world-leaders-areshocked-worried-by-storming-of-u-s-capitol-by-trump-suppo rters-11609971098.

Powell, R. 1994. Anarchy in international relations theory: The neorealist-neoliberal debate. International Organization 48: 313-344.

Quealy, K. January 19, 2021. The complete list of Trump's Twitter insults (2015-2021). The New York Times. https://www.nytimes. com/interactive/2021/01/19/upshot/trump-complete-insult-list. html? referringSource $=$ articleShare $\&$ fbclid $=$ IwAR0e-iwSjU sESomtiik1NVXRRPduL6cAmWS9HnRts8wHqopmtP461yl rjWU\#.

Rodden, J. 2020. The Orwellian "Amerika" of DonaldTrump? Society, 57(3), 260-264. https://doi.org/10.1007/s12115-020-00476-5.

Romo, V. 2020. NFL on kneeling players' protests: 'We were wrong', Commissioner says. $n p r$. https://www.npr.org/sections/live-updat es-protests-for-racial-justice/2020/06/05/871290906/nfl-on-kneel ing-players-protests-we-were-wrong-commissioner-says.

Ross, A.S., and D. Caldwell. 2020. 'Going negative': an APPRAISAL analysis of the rhetoric of Donald Trump on Twitter. Language \& Communication 70: 13-27. https://doi.org/10.1016/j.langcom. 2019.09 .003$.
Schmidt, S.H., E.L. Frederick, A. Pegoraro, and T.C. Spencer. 2018. An analysis of Colin Kaepernick, Megan Rapinoe, and the National Anthem Protests. Communication \& Sport 7 (5): 653 677. https://doi.org/10.1177/2167479518793625.

Schneiker, A. 2020. Populist leadership: the superhero Donald Trump as Savior in times of crisis. Political Studies 68 (4): 857-874. https://doi.org/10.1177/0032321720916604.

Schuhmann, J. September 14, 2019. After 7th place finish, Team USA reflects on what when wrong, next steps. NBA. https://www.nba. com/news/team-usa-postmortem-world-cup.

Schwarzenegger, A. [@ Schwarzenegger]. January 10, 2021. My message to fellow Americans and friends around the world following this week's attack on the Capitol. Twitter. https://twitter.com/ Schwarzenegger/status/1348249481284874240.

Seddiq, O. November 20, 2020. Here are all the Trump officials who have been fired or resigned since the president's election defeat. Business Insider. https://www.businessinsider.com/trump-offic ials-fired-or-resigned-since-election-2020-11.

Sgobba, C. October 11, 2019. After Salazar ban, Nike shuts down Oregon Project. Runner's World. https://www.runnersworld.com/ news/a29432537/nike-shuts-down-oregon-project/.

Shewfelt, R. February 3, 2020. Jennifer Lopez explains the political statement in her Super Bowl performance: 'All of us together are what makes this beautiful country truly great'. Yahoo! entertainment. https://www.yahoo.com/entertainment/jennifer-lopez-polit ical-statement-super-bowl-performance-033812595.html.

Signitzer, B.H., and T. Coombs. 1992. Public relations and public diplomacy: conceptual convergences. Public Relations Review 18 (2): 137-147.

Silva, D., N. Kalman-Lamb, J. Mellis. August 12, 2020. Cancelling the college football season is about union busting, not health. The Guardian. https://www.theguardian.com/sport/2020/aug/ $12 /$ cancelling-the-college-football-season-is-about-union-busti ng-not-health.

Sims, C. February 12, 2018. What happened between Adam Rippon and Vice President Mike Pence, IndyStar. https://www.indystar. com/story/news/2018/02/12/what-happened-between-adam-rippon-and-vice-president-mike-pence/328604002/.

Solo, H. [@ hopesolo]. January 21, 2017. Time to march! \#WomensMarch [Tweet]. Twitter. https://twitter.com/hopesolo/status/ 822890549464035328.

Step in, Dream Big. (n.d). Empowering girls and women through sports. Bureau of Educational and Cultural Affairs. https://eca. state.gov/stepindreambig/.

Sterling, W., and S. Almasy. August 21, 2019. American gold medalists reprimanded after protests at Pan American Games. CNN. https:// edition.cnn.com/2019/08/21/sport/usa-fencer-hammer-throwerprotests-suspensions/index.html.

Team USA. 2020. Sponsors. https://www.teamusa.org/sponsors.

Team USA. (n.d.). Susanne Lyons Board Chair. https://www.teamu sa.org/About-the-USOPC/Leadership/Board-of-Directors/Susan ne-Lyons.

The Daily Show with Trevor Noah. June 15, 2019. The U.S. Women's World Cup Team gets slammed for over-celebrating. YouTube. https://www.youtube.com/watch?v=C--hgPKcP3Q.

The Good Country Index. (n.d.). 1.4. The Good Country. https://index. goodcountry.org/?fbclid=IwAR0MeIICz8DZ_c_ce_4wuDi WX9ErDuoWhCKTVS2M8-36SPiksDrIWLqqHCs.

The Players' Tribune. August 2, 2020. \#WeAreUnited. The Players' Tribune. https://www.theplayerstribune.com/articles/pac-12players-covid-19-statement-football-season.

Time Staff. June 16, 2015. Here's Donald Trump's Presidential Announcement Speech. Time. https://time.com/3923128/donald-trump-announcement-speech/. 
Tinsley, J. November 20, 2017. Trump VS. the wide world of sports: A timeline. The Undrafted. https://theundefeated.com/features/ trump-vs-the-wide-world-of-sports-a-timeline/.

TSN.ca staff. January 7, 2020. Sports world reacts to chaos in Washington, D.C. TSN. https://www.tsn.ca/sports-world-reacts-to-chaosunfolding-in-washington-d-c-as-armed-protesters-storm-capit ol-1.1573494.

United States Olympic Committee. September 13, 2017. Los Angeles awarded 2028 Olympic and Paralympic Games. Team USA. https://www.teamusa.org/news/2017/september/13/los-angelesawarded-2028-olympic-and-paralympic-games.

United States Olympic \& Paralympic Committee. 2019, June 20. U.S. Olympic Committee changes name to U.S. Olympic \& Paralympic Committee. Team USA. https://www.teamusa.org/News/ 2019/June/20/US-Olympic-Committee-Changes-Name-To-USOlympic-Paralympic-Committee.

Vasquez, M., \& Carvajal, C. August 10, 2020. Trump calls on college football games to resume amid coronavirus pandemic. CNN. https://www.cnn.com/2020/08/10/politics/donald-trump-colle ge-football-coronavirus/index.html.

West, J. December 10, 2020. USOPC will not sanction athletes for peaceful social justice protests at Olympics. SI. https://www. si.com/olympics/2020/12/10/olympics-peaceful-social-justiceprotests-not-sanctioned-usopc.

White, C.J. 2015. Exploring the role of private-sector corporations in public diplomacy. Public Relations Inquiry 4: 305-321.
White House. (n.d.). Medal of Freedom. https://www.whitehouse.gov/ medaloffreedom/.

Woods, R.B., and B.N. Butler. 2021. Social issues in sport, 4th ed. Champaign, IL: Human Kinetics.

Zillgitt, J. March 27, 2018. Spurs coach Gregg Popovich on guns: It's time to reassess the Second Amendment. USA Today. https:// www.usatoday.com/story/sports/nba/2018/03/27/spurs-coachgregg-popovich-guns-reassess-second-amendment/464350002/.

Ziller, T. July 25, 2019. Why are American NBA starts skipping the FIBA World Cup? SBNation. https://www.sbnation.com/2019/7/ 22/20703463/team-usa-basketball-fiba-world-cup-players-left.

Publisher's Note Springer Nature remains neutral with regard to jurisdictional claims in published maps and institutional affiliations.

Yoav Dubinsky (Ph.D., University of Tennessee, Knoxville), Instructor, Department of Marketing, Lundquist College of Business, University of Oregon. Dr. Dubinsky's research interests include sports, country image, nation branding, and public diplomacy, especially in the contexts of global sports, the Olympic Movement, Israel, and/or the United States. 